\title{
PERSONNEL PLANNING OF A RETAIL STORE USING POS DATA
}

\author{
Liu, Y. \\ Nagoya University, Graduate School of Economics and Business Administration, \\ Furo-cho, Chikusa-ku, Nagoya, Aichi, 464-8601, Japan \\ E-Mail: liu.yan@g.mbox.nagoya-u.ac.jp
}

\begin{abstract}
The competitiveness of retail stores depends heavily on the ability to handle the challenges of reducing control costs and increasing customer service levels. One element that affects cost significantly is labour costs. This paper addresses proposing a procedure of finding the optimal solutions of personnel planning, especially by making use of the actual Point of Sales (POS) data and considering several frequency patterns of customers entering a store. First, a simulation model of the payment process is designed to establish the conditions for an integer programming (IP) model. Second, this study proposes the IP model to find the initial optimal patterns of salesclerk allocation; that is, the allocation pattern is optimal at each interval. Finally, the simulation model is used to examine the service level. With the assistance of the simulation result, the optimal solution can be obtained to satisfy a predefined service level by repeating the simulation model.

(Received in February 2009, accepted in June 2009. This paper was with the author 1 month for 1 revision.)
\end{abstract}

Key Words: POS, Personnel Scheduling, Integer Programming

\section{INTRODUCTION}

Problems related to personnel scheduling have been studied for many years due to the importance of planning in the overall performance of a business in terms of quality of service to the customer and cost to the organization [1]. For instance, Takakuwa and Okada [2] proposed that simulation modelling in conjunction with integer programming and directsearch methods can be used for operations planning of a inbound call centre to minimise personnel expenses. Takakuwa and Wijewickrama [3] developed a discrete-event-simulation to optimise doctor schedules in all departments of an outpatient hospital ward of the Nagoya University hospital. Wijewickrama and Takakuwa [4] presented a simulation analysis of patient flow aiming to shorten waiting time by identifying an optimum doctor mix. The objective of all above studies was to minimise personnel expenses or achieve increased satisfaction in service levels.

In the recent decade, POS system has been spread quickly among Japanese retailers because it is an accurate data management to respond more accurately and quickly to sales trends. As the competition in retail industry increases, retailers are becoming much more obligated to optimise their store performance [5]. Simulation has been a widely accepted tool in analyzing performance in the service industry (e.g., [6]). Several studies have focused on various issues concerned with POS data. For instance, Fu and Piplani [7] developed a model making use of POS data for collaborative inventory management in supply chains. King and Moon [8] used POS data for a case study about quick response replenishment. Joines et al. [9] employed POS data for multi-objective optimisation. Adams, Flatto and Gardner [10] applied POS data in spreadsheets simulation of Beer Game. Miwa and Takakuwa [11] presented a procedure of simulation modelling for in-store merchandizing in order to examine customer flows in retail stores. At present, the review of literature indicates that no studies have been 
conducted regarding personnel planning using POS data. The purpose of this paper differs from previous research because a simulation based approach is developed to optimise personnel planning of a retail store using actual POS data.

This paper discusses a simulation-IP based approach of optimizing a retail store's personnel planning, especially by making use of the Point of Sales (POS) data. First, the past two years POS data was carefully reviewed in order to analyse the frequency of customers coming into the store. Thereafter, due to the correlation coefficients of the data several frequency patterns of customers were drawn. Then, a stepwise procedure of personnel scheduling was proposed to minimise the total personnel expenses, by performing simulation models together with integer programming.

\section{BASIC DESCRIPTION OF THE RETAIL STORE}

FamilyMart Company Limited represents Japan's third largest franchise chain of convenience stores. Worldwide, FamilyMart has more than 13,000 stores and is growing quickly in other parts of Asia. As a collaborated study project between Nagoya University and FamilyMart, the company provided POS data constantly from the store on the campus of Nagoya University which opened on 20 July, 2006. The shop's open time was from 7AM to 11PM. Sales items were available as well as any other Japanese convenience store, such as basic grocery items, magazines, comic books, soft drinks, and snack foods.

Fig. 1 illustrates the flow of the cash register service. First, salesclerks remove goods from a shopping basket, scanning each product. After shopping items being bagged, customers finish the payment and leave the store. As shown in Fig. 1, the service process of payment checking can be done by one salesclerk (a) or two salesclerks (b). The occasion of (b) can serve more customers than (a) do in the same time interval.

Table I lists the patterns of salesclerk allocation in this store. As a priority assignment, the store manager was eager to minimise personnel expenses without affecting service levels. Some sort of powerful decision-making tools are needed in order to gain such a management goal of planning. These decisions may be simply defined as "How many salesclerks to be required properly" or even described as more complex decision forecasting models as "When and which pattern of salesclerk allocation be optimal to the store". This paper addresses optimizing these resource decisions in retail stores in order to determine robust solutions.

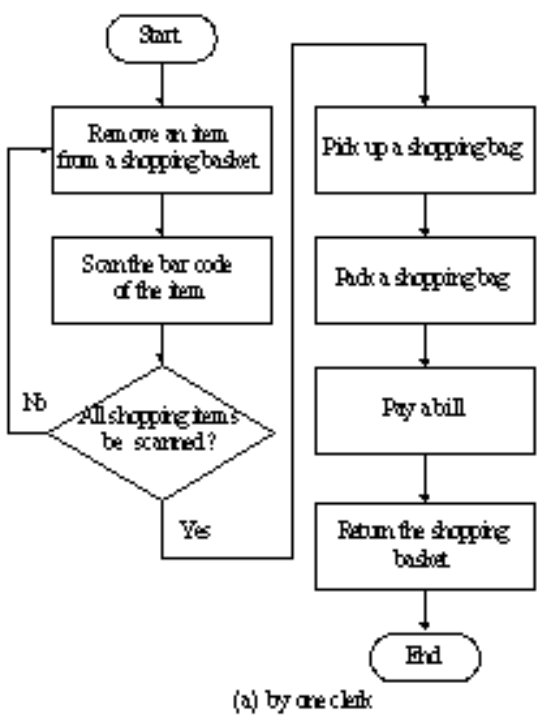

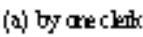

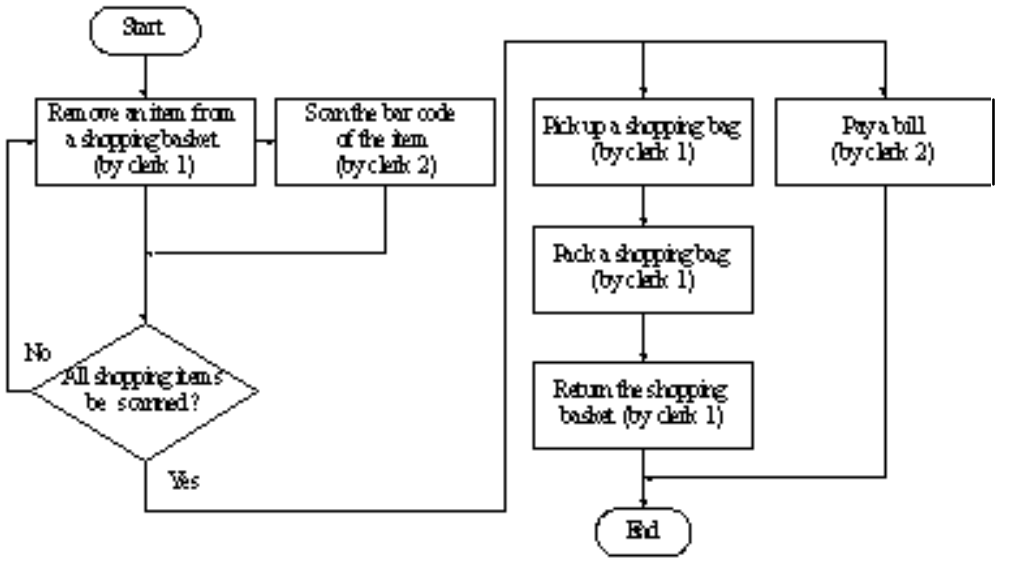

bis batabs

Figure 1: The flow of cash register service. 
Table I: Patterns of salesclerks' allocation.

\begin{tabular}{|c|c|c|c|c|c|c|c|c|}
\hline \multicolumn{2}{|c|}{ Register No. } & 1 & 2 & 3 & 4 & $\begin{array}{c}\text { Total number } \\
\text { of salesclerks }\end{array}$ & $\begin{array}{c}\text { Total number } \\
\text { of cash registers }\end{array}$ & $\begin{array}{c}\text { Personnel cost } \\
\text { ( yen/hour) }\end{array}$ \\
\hline \multirow{4}{*}{$\begin{array}{c}\text { Allocation } \\
\text { Patterns }\end{array}$} & 1 & 1 & - & - & - & 1 & 1 & 750 \\
\cline { 2 - 9 } & 3 & 1 & 1 & - & - & 2 & 2 & 1,500 \\
\cline { 2 - 9 } & 5 & 1 & 1 & 1 & - & 3 & 3 & 2,250 \\
\cline { 2 - 9 } & 6 & 2 & 1 & 1 & 1 & 4 & 4 & 3,000 \\
\hline
\end{tabular}

\section{PRELIMINARY ANALYSES}

Fig. 2 reflects a six week period of the central tendency of traffic during the work week over the past two years in the store (from 20 July, 2006 to 31 July, 2008). Therefore, six data-sets of the periods were prepared from POS data. Table II assists in defining the six periods under study for this paper.

Fig. 3 illustrates the waves of number of customers for every 15 minutes for the weekday period of July 2008. The peak time at this store was mid-day lunchtime (approximately 12:00PM-1:00PM) and times for class break (approximately 8:30AM-8:45AM; 10:15AM10:30AM; 2:30PM-2:45PM; 4:15PM-4:30PM; 6:00PM-6:15PM). During the peak time, customer waiting time was often quite lengthy. The author found it interesting that the optimal salesclerk allocation was to minimise daily personnel expenses without affecting customer service level at the bottlenecks.

A third period data-set assisted to quantify a correlation coefficient between each number of customers at the quarter-hour. Table III provides evidence for a greater degree of linear relationship. This result was important in the simulation model as the data-sets were used to generate the relative number of customer entities.

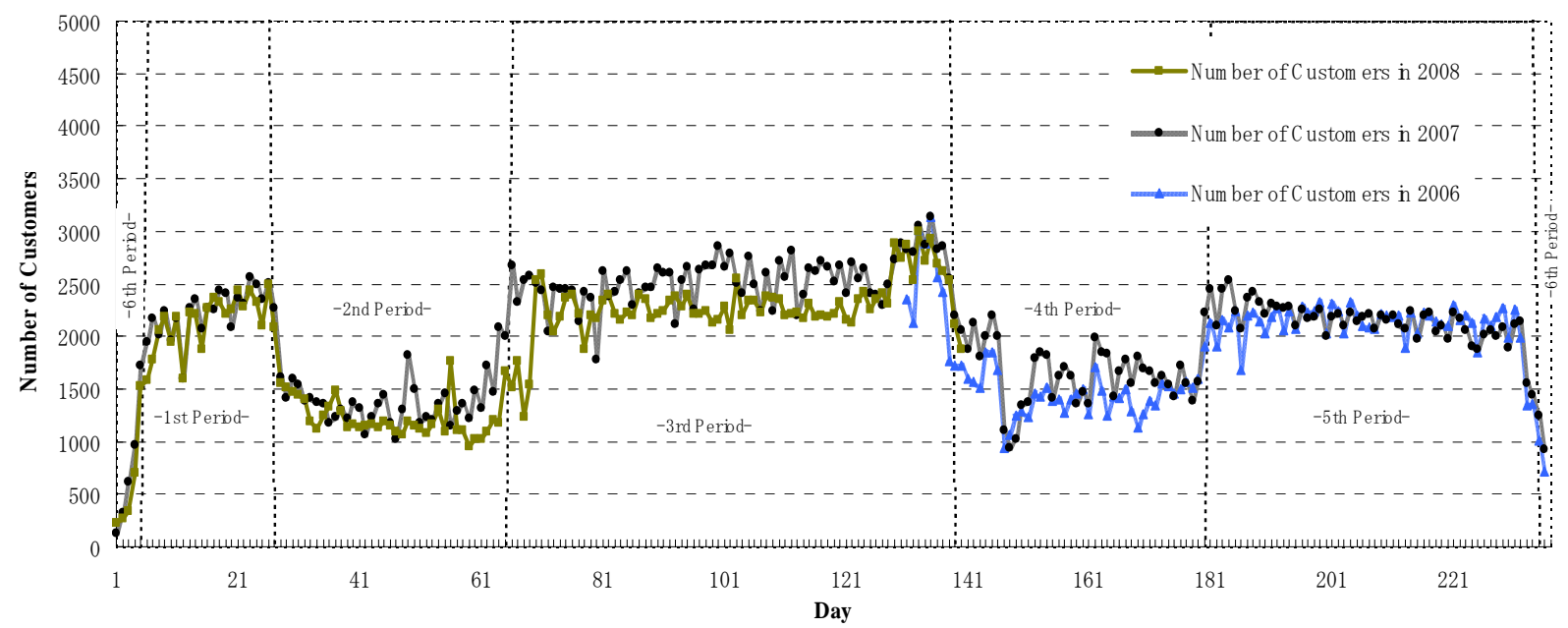

Figure 2: The change in the number of customers during the work week. 
Table II: A six week period for data-sets.

\begin{tabular}{|c|c|c|}
\hline Period No. & Period & Date \\
\hline 6 & Winter Vacation-1 & $2008 / 1 / 1-2008 / 1 / 7$ \\
\hline 1 & Resumption of Fall Semester & $2008 / 1 / 8-2008 / 2 / 6$ \\
\hline 2 & Spring Vacation & $2008 / 2 / 7-2008 / 4 / 4$ \\
\hline 3 & Spring Semester & $2008 / 4 / 5-2008 / 7 / 31$ \\
\hline 4 & Summer Vacation & $2008 / 8 / 1-2008 / 9 / 26$ \\
\hline 5 & Fall Semester & $2008 / 9 / 27-2008 / 12 / 22$ \\
\hline 6 & Winter Vacation-2 & $2008 / 12 / 23-2008 / 12 / 31$ \\
\hline
\end{tabular}

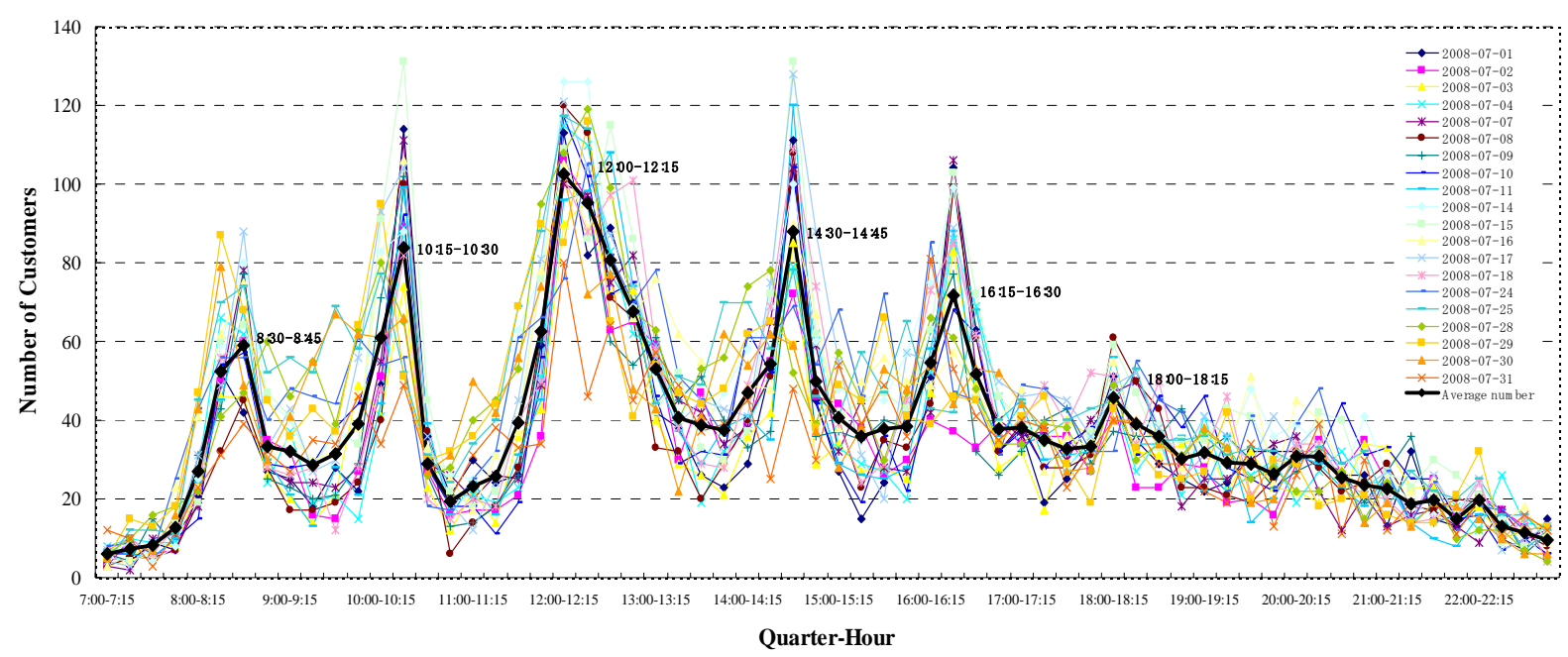

Figure 3: The waves of number of customers in 15-minutes intervals.

Table III: Correlation coefficient of number of customers in 15-minutes intervals.

\begin{tabular}{|c|c|c|c|c|c|c|c|c|c|}
\hline & & 2008-07-01 & 2008-07-02 & 2008-07-03 & 2008-07-04 & 2008-07-07 & 2008-07-08 & 2008-07-09 & $2008-07-10$ \\
\hline \multirow{2}{*}{ 2008-07-01 } & Pearson Correlation & 1 & $.819(\star *)$ & $.909(\star \star)$ & 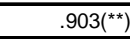 & $.925\left({ }^{(\star)}\right.$ & $.942(\star *)$ & $.8611^{(\star *)}$ & $.896(\star \star)$ \\
\hline & Sig. (2-tailed) & & $1.24896 \mathrm{E}-16$ & $2.84318 \mathrm{E}-25$ & $1.76833 \mathrm{E}-24$ & $7.85172 \mathrm{E}-28$ & $5.42117 \mathrm{E}-31$ & $7.92101 \mathrm{E}-20$ & $1.61424 \mathrm{E}-23$ \\
\hline \multirow{2}{*}{ 2008-07-02 } & Pearson Correlation & $.819(\star *)$ & 1 & $.854(\star \star)$ & $.885\left({ }^{\star \star}\right)$ & $.869(\star \star)$ & $.849(\star *)$ & $.881(\star \star)$ & $\left..890^{(\star \star}\right)$ \\
\hline & Sig. (2-tailed) & $1.25 \mathrm{E}-16$ & & $3.06783 \mathrm{E}-19$ & $3.09285 \mathrm{E}-22$ & $1.38718 \mathrm{E}-20$ & $7.57534 \mathrm{E}-19$ & $7.45327 \mathrm{E}-22$ & $8.75158 \mathrm{E}-23$ \\
\hline \multirow{2}{*}{ 2008-07-03 } & Pearson Correlation & $.909(\star \star)$ & $.854(\star \star)$ & 1 & $.8922^{(\star)}$ & $.896(\star *)$ & $.928\left({ }^{* \star}\right)$ & $.867(\star \star)$ & $.928(\star \star)$ \\
\hline & Sig. (2-tailed) & $2.84318 \mathrm{E}-25$ & $3.06783 \mathrm{E}-19$ & & $4.25403 \mathrm{E}-23$ & $1.74753 \mathrm{E}-23$ & $2.80987 \mathrm{E}-28$ & $1.9859 \mathrm{E}-20$ & $2.61353 \mathrm{E}-28$ \\
\hline \multirow{2}{*}{ 2008-07-04 } & Pearson Correlation & $.903{ }^{(\star *)}$ & $.885\left({ }^{(\star)}\right.$ & $.892(\star \star)$ & & $.914\left({ }^{\star \star}\right)$ & $.912\left({ }^{\star \star}\right)$ & $.852(* \star)$ & $.9044^{(\star)}$ \\
\hline & \begin{tabular}{|l} 
Sig. (2-tailed) \\
\end{tabular} & 1.76833E-24 & 3.09285E-22 & 4.25403E-23 & & $6.55477 \mathrm{E}-26$ & $1.04225 \mathrm{E}-25$ & 4.33174E-19 & 1.36113E-24 \\
\hline \multirow{2}{*}{ 2008-07-07 } & Pearson Correlation & $.925\left({ }^{*}\right)$ & $.869\left(^{(*)}\right.$ & $.896\left({ }^{\star *}\right)$ & 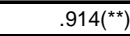 & 1 & .921(**) & $.892\left({ }^{(\star)}\right.$ & .881 \\
\hline & Sig. (2-tailed) & $7.85172 \mathrm{E}-28$ & $1.38718 \mathrm{E}-20$ & $1.74753 \mathrm{E}-23$ & $6.55477 \mathrm{E}-26$ & & $4.07332 \mathrm{E}-27$ & $4.14417 \mathrm{E}-23$ & $7.33459 \mathrm{E}-22$ \\
\hline \multirow{2}{*}{$2008-07-08$} & Pearson Correlation & $.942\left({ }^{(\star)}\right.$ & $.849\left({ }^{*}\right)$ & $.928\left({ }^{\star *}\right)$ & $.912(\star \star)$ & $.921\left({ }^{\star \star}\right)$ & 1 & $.869\left({ }^{* *}\right)$ & $.917\left(^{\star \star}\right)$ \\
\hline & Sig. (2-tailed) & $5.42117 \mathrm{E}-31$ & $7.57534 \mathrm{E}-19$ & $2.80987 \mathrm{E}-28$ & $1.04225 \mathrm{E}-25$ & $4.07332 \mathrm{E}-27$ & & $1.44665 \mathrm{E}-20$ & $1.66319 \mathrm{E}-26$ \\
\hline \multirow{2}{*}{ 2008-07-09 } & Pearson Correlation & $.861\left({ }^{(\star)}\right.$ & $\left..8811^{\star \star}\right)$ & $.867\left({ }^{\star *}\right)$ & $.852\left({ }^{(\star)}\right)$ & $.892\left({ }^{(*)}\right)$ & $.869\left(^{(\star)}\right.$ & 1 & $.877\left(^{(\star)}\right.$ \\
\hline & Sig. (2-tailed) & $7.92101 \mathrm{E}-20$ & 7.45327E-22 & $1.9859 \mathrm{E}-20$ & $4.33174 \mathrm{E}-19$ & $4.14417 \mathrm{E}-23$ & $1.44665 \mathrm{E}-20$ & & $2.02953 \mathrm{E}-21$ \\
\hline \multirow{2}{*}{$2008-07-10$} & Pearson Correlation & $.896\left(^{(*)}\right.$ & $.8900^{(\star)}$ & $.928(* \star)$ & $.904\left({ }^{\star *}\right)$ & $.881(\star \star)$ & $.917(\star *)$ & $.877^{(\star *)}$ & \\
\hline & Sig. (2-tailed) & $1.61424 \mathrm{E}-23$ & $8.75158 \mathrm{E}-23$ & $2.61353 \mathrm{E}-28$ & $1.36113 \mathrm{E}-24$ & $7.33459 \mathrm{E}-22$ & $1.66319 \mathrm{E}-26$ & $2.02953 \mathrm{E}-21$ & \\
\hline
\end{tabular}

\section{PROCEDURES TO SEEK THE OPTIMAL SOLUTION}

\subsection{The procedures}

Computer simulation is a methodology that can be used to describe, analyse and predict the performance of a complex business process without the limiting assumptions. On the other 
hand, IP is a mathematical procedure concerned with determining the optimal allocation of scarce resources [12]. The objective in this study is to minimise the total daily personnel expenses, satisfying a certain service level target for a number of customers expected coming into a store. The performance measure within the store is the service level, defined as the percentage of customers served within some fixed time period, known as the service level target. For instance, when $95 \%$ of customers were served within one minute, then the service level was simply denoted as 95/60 seconds. The service level target must be set before performing the proposed procedures. Constrained optimisation is performed because the service level target is a constraint. As shown in the following Fig. 4, the procedures to seek the optimal solution are itemised as follows:

[Step 1] An expected number of customers sampling or sampling data of a certain day from a customer dataset of sales is selected randomly in Visual Basic for Applications (VBA) in Microsoft Excel, as shown in Fig. 5. Customer dataset of sales and Customer dataset of detailed sales are shown in Tables IV and V. The six shaded columns are actually used to perform simulation models.

[Step 2] Using the Microsoft Access relationship facility, detailed sales data is retrieved and stored in another database. Sales data and selected detailed sales data (called "complete data-set”) are used to perform a simulation model.

[Step 3] Simulation model mimics the service process based on the flow of cash register service demonstrated in Fig. 1.

[Step 4] Simulation results are obtained such as the capacity of the payment process. For instance, how many customers can be served in every 15-minutes interval.

[Step 5] An IP model is built by using of simulation output results as constraints.

[Step 6] An initial optimal solution is obtained by performing IP model.

[Step 7] The initial optimal result from IP model is inputted into simulation model to analyse customer waiting time.

[Step 8] The average customer waiting time for each interval is examined as a performance measure of simulation experiments. Check the simulation output to see whether service level target is satisfied, if not, this means the clerk capacity is insufficient, then another salesclerk member needs to be added to the interval in which the service level is minimum. Repeat Step 7 until the service level target is satisfied.
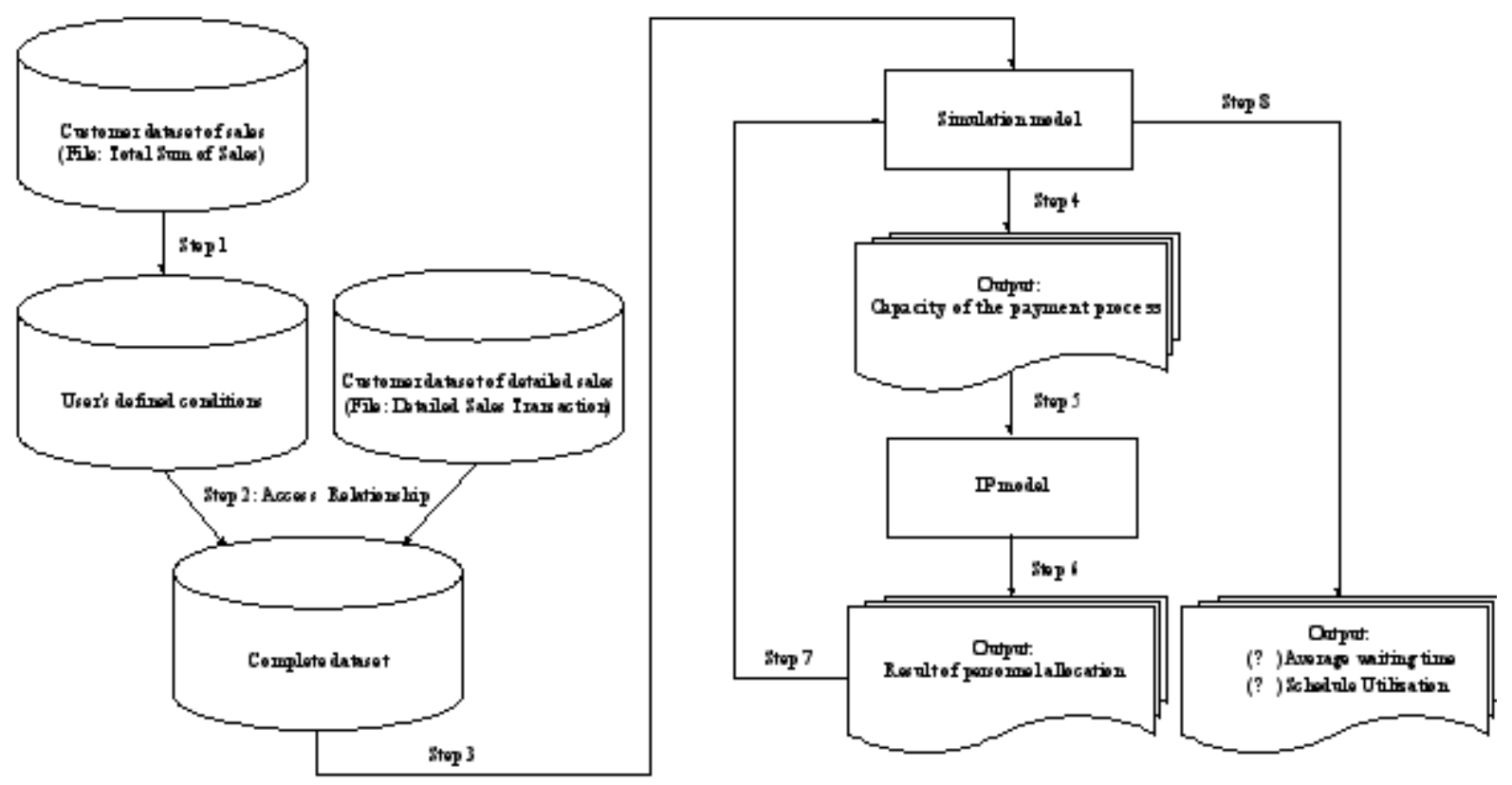

Figure 4: Flowchart of the proposed procedures. 


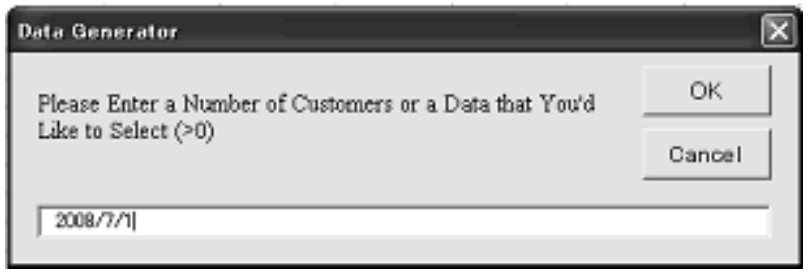

Figure 5: Excel VBA for selecting data.

Table IV: Customer data-set of sales.

\begin{tabular}{|c|c|c|c|c|c|c|c|c|c|c|c|c|c|c|c|c|c|}
\hline $\begin{array}{l}\text { Date of } \\
\text { Sales }\end{array}$ & Store ID & Store Name & $\begin{array}{c}\text { Register } \\
\text { No. }\end{array}$ & $\begin{array}{c}\text { Transaction } \\
\text { No. }\end{array}$ & $\begin{array}{l}\text { Time of } \\
\text { Sales } \\
\text { (hour) }\end{array}$ & $\begin{array}{c}\text { Time of } \\
\text { Sales } \\
\text { (min.) }\end{array}$ & $\begin{array}{c}\text { Customer } \\
\text { Type }\end{array}$ & F/M, Age & $\begin{array}{c}\text { No. of } \\
\text { Sales } \\
\text { Items }\end{array}$ & $\begin{array}{c}\text { Total Sum } \\
\text { of Sales }\end{array}$ & $\begin{array}{c}\text { Flag on } \\
\text { Using } \\
\text { Prepaid } \\
\text { Card }\end{array}$ & $\begin{array}{c}\text { Flag on } \\
\text { Using IC } \\
\text { Card }\end{array}$ & $\begin{array}{l}\text { Name } \\
\text { of IC } \\
\text { Card }\end{array}$ & $\begin{array}{c}\text { IC } \\
\text { Card } \\
\text { No. }\end{array}$ & \begin{tabular}{|c|} 
Flag on \\
Using \\
Card
\end{tabular} & $\begin{array}{c}\text { Transaction } \\
\text { Code }\end{array}$ & Name of Transaction \\
\hline 2008-07-01 & 54858 & Nagoya-U. & 01 & 7 & 10 & 24 & 03 & 20's M & 2 & 225 & 0 & 0 & Non- $\mathrm{d}$ & 0 & 0 & 1000 & Regular Registration \\
\hline 2008-07-01 & 54858 & Nagoya-U. & 01 & 8 & 10 & 24 & 03 & 20's M & 1 & 160 & 0 & 0 & Non- $\mathrm{d}$ & 0 & 0 & 1000 & Regular Registration \\
\hline \multirow[t]{2}{*}{ 2008-07-01 } & 54858 & Nagoya-U. & 01 & 9 & 10 & 24 & 03 & 20's F & 3 & 130 & 0 & 0 & Non- $\mathrm{C}$ & 0 & 0 & 1000 & Regular Registration \\
\hline & & $\cdots$ & $\cdots$ & $\cdots$ & $\ldots$ & $\cdots$ & $\cdots$ & $\cdots$ & $\cdots$ & $\cdots$ & $\cdots$ & $\ldots$ & $\cdots$ & $\cdots$ & $\cdots$ & $\cdots$ & $\cdots$ \\
\hline 2008-07-01 & 54858 & Nagoya-U. & 01 & 17 & 10 & 28 & 03 & 20's M & 1 & 144 & 0 & 0 & Non- $\mathrm{D}$ & 0 & 0 & 1000 & Regular Registration \\
\hline 2008-07-01 & 54858 & Nagoya-U. & 01 & 18 & 10 & 29 & 03 & 20's M & 1 & 100 & 0 & 0 & Non- $\mathrm{d}$ & 0 & 0 & 1000 & Regular Registration \\
\hline 2008-07-01 & 54858 & Nagoya-U. & 01 & 19 & 10 & 30 & 03 & 20's M & 1 & 100 & 0 & 0 & Non- $\mathrm{d}$ & 0 & 0 & 1000 & Regular Registration \\
\hline
\end{tabular}

Table V: Customer data-set of detailed sales.

\begin{tabular}{|c|c|c|c|c|c|c|c|c|c|c|c|c|c|c|c|c|c|c|c|}
\hline Date of Sales & $\begin{array}{c}\text { Store } \\
\text { ID }\end{array}$ & $\begin{array}{l}\text { Store } \\
\text { Name }\end{array}$ & $\begin{array}{c}\text { Register } \\
\text { No. }\end{array}$ & $\begin{array}{c}\text { Transaction } \\
\text { No. }\end{array}$ & $\begin{array}{c}\text { Time of } \\
\text { Sales } \\
\text { (hour) }\end{array}$ & \begin{tabular}{|l} 
Time of \\
Sales \\
(min.)
\end{tabular} & $\begin{array}{c}\text { Detail } \\
\text { No. }\end{array}$ & $\begin{array}{c}\text { Item } \\
\text { Group } \\
\text { ID }\end{array}$ & $\begin{array}{c}\text { Name of } \\
\text { Item Group }\end{array}$ & FM Code & $=\begin{array}{c}\text { Name of } \\
\text { Goods in } \\
\text { Region }\end{array}$ & $\begin{array}{l}\text { Designated } \\
\text { Goods No. }\end{array}$ & \begin{tabular}{|c|} 
Truck- \\
Delivery \\
No. \\
\end{tabular} & \begin{tabular}{|c|}
$\begin{array}{c}\text { Code of } \\
\text { Detailed } \\
\text { Sales } \\
\text { Transaction }\end{array}$ \\
\end{tabular} & $\begin{array}{l}\text { Name of Detailed } \\
\text { Sales Transaction }\end{array}$ & $\begin{array}{c}\text { Register } \\
\text { ID }\end{array}$ & $\begin{array}{c}\text { Name of } \\
\text { Nominal } \\
\text { accout }\end{array}$ & $\begin{array}{l}\text { No. of } \\
\text { Sales } \\
\text { Items }\end{array}$ & $\begin{array}{c}\text { Total } \\
\text { Sum of } \\
\text { Sales }\end{array}$ \\
\hline 2008-07-01 & 54858 & Nagoya-U & 01 & 7 & 10 & 24 & 1 & 174 & \begin{tabular}{|l} 
Chilled \\
Juice
\end{tabular} & 17432340 & Vegetables & 325320 & 01 & 2400 & (Included Tax) PLU & 03 & Food & 1 & 80 \\
\hline 2008-07-01 & 54858 & Nagoya-U & 01 & 7 & 10 & 24 & 2 & 025 & \begin{tabular}{|l|}
$\begin{array}{l}\text { Sandwich- } \\
\text { 1st }\end{array}$ \\
\end{tabular} & 02532220 & Smoke Saln & 246103 & 01 & 2410 & (Included Tax) PLU & 03 & Food & 1 & 143 \\
\hline 2008-07-01 & 54858 & Nagoya-U & 01 & 8 & 10 & 24 & 1 & 091 & \begin{tabular}{|l} 
Sweet \\
Bread
\end{tabular} & 09116890 & Chocolate D & 340610 & 01 & 2400 & (Included Tax) PLU & 03 & Food & 1 & 160 \\
\hline 2008-07-01 & 54858 & Nagoya-U & 01 & 9 & 10 & 24 & 1 & 153 & $\begin{array}{l}\text { Sugar } \\
\text { Candy }\end{array}$ & 47558690 & Cola Bitters & 340049 & 01 & 2400 & (Included Tax) PLU & 03 & Food & 1 & 130 \\
\hline$\cdots$ & $\cdots$ & $\cdots$ & $\cdots$ & $\cdots$ & $\cdots$ & $\cdots$ & $\cdots$ & $\cdots$ & $\ldots$ & $\cdots$ & $\cdots$ & $\cdots$ & $\cdots$ & $\cdots$ & $\cdots$ & $\cdots$ & $\cdots$ & $\cdots$ & $\cdots$ \\
\hline 2008-07-01 & 54858 & Nagoya-U & 01 & 9 & 10 & 24 & 1 & 475 & Coffee & 42123310 & Boss No Su & 326947 & 01 & 2400 & (Included Tax) PLU & 03 & Food & 2 & 20 \\
\hline 2008-07-01 & 54858 & Nagoya-U & 01 & 10 & 10 & 24 & 1 & 172 & P-candy & 47257940 & Mitsuya & 319841 & 01 & 2400 & (Included Tax) PLU & 03 & Food & 1 & 138 \\
\hline $008-07-01$ & 54858 & Nagoya-U & 01 & 11 & 10 & 25 & 1 & 421 & Coffee & 42123310 & Boss No Su & 266224 & 01 & 2400 & (Included Tax) PLU & 03 & Food & 1 & 115 \\
\hline
\end{tabular}

\subsection{Integer programming model}

An IP problem is a linear program in which all of the variables are restricted to integer values [13]. The problem in this study is to determine the optimal allocation pattern that serves customers. The objective is to minimise the total daily personnel expenses where different allocation patterns have different personnel expenses. By using a matrix notation, an IP model may be written as follows:

Define the decision variable

$$
x_{i, j}=1 \text { if allocation pattern } i \text { is used, }=0 \text { if not used; for } j=1,2, \ldots, J \text {. }
$$

Find $x_{i, j}$ so as to

$$
\text { minimise } \sum_{i=1}^{I} \sum_{j=1}^{J} h_{i, j} x_{i, j}
$$

subject to:

$$
\begin{gathered}
\sum_{i=1}^{I} x_{i, j}=1 \quad(j=1,2, \ldots, J) \\
\sum_{i=1}^{I} k_{i, j} x_{i, j} \geq S_{j} \quad(j=1,2, \ldots, J) \\
x_{i, j}=0, \text { or } 1(i=1,2, \ldots, I ; j=1,2, \ldots, J)
\end{gathered}
$$


Where:

$h_{i, j} \quad$ - total personnel expense $j$ interval with allocation pattern $i$ (Yen),

$i \quad$ - index for allocation pattern,

I - number of allocation patterns,

j $\quad$ - index for intervals,

$J \quad$ - number of intervals,

$k_{i, j} \quad$ - expected number of customers to be served by corresponded allocation pattern $i$ (persons),

$S_{j} \quad$ - number of customers appearing at interval $j$ (persons).

Eq. (1) is a constraint in which only one allocation pattern can be selected in every interval, $k_{i, j}$, and $S_{j}$ are shown in Eq. (2) and outputted from the simulation models. The Eq. (2) is another constraint for each interval, stating that allocation pattern $i$ that be used can serve $S_{j}$ persons.

\section{APPLICATION}

This section will discuss the applied procedures in an actual case where the service level target was set as 95/60 seconds. At Step 1, the sales data of 1 July, 2008 was selected in this study, so that it is easy to compare the optimal solution with current personnel allocation status. Here, the current personnel allocation status was called "AS-IS". Then detailed sales data of 1 July, 2008 is retrieved by making use of the Microsoft Access relationship facility for Step 2.

For Step 3, the store simulation model was developed to establish the conditions for the IP model. The simulation models were created using Arena [14]. The selected simulation parameters are given in Table VI. Fig. 6 provides an illustration of one part of the animation from the models. Fig. 7 shows the simulation results from Step 4, which includes the number of customers served every 15 minutes by either one or two salesclerks. Fig. 8 gives the number of customers appearing in every 15 minutes intervals.

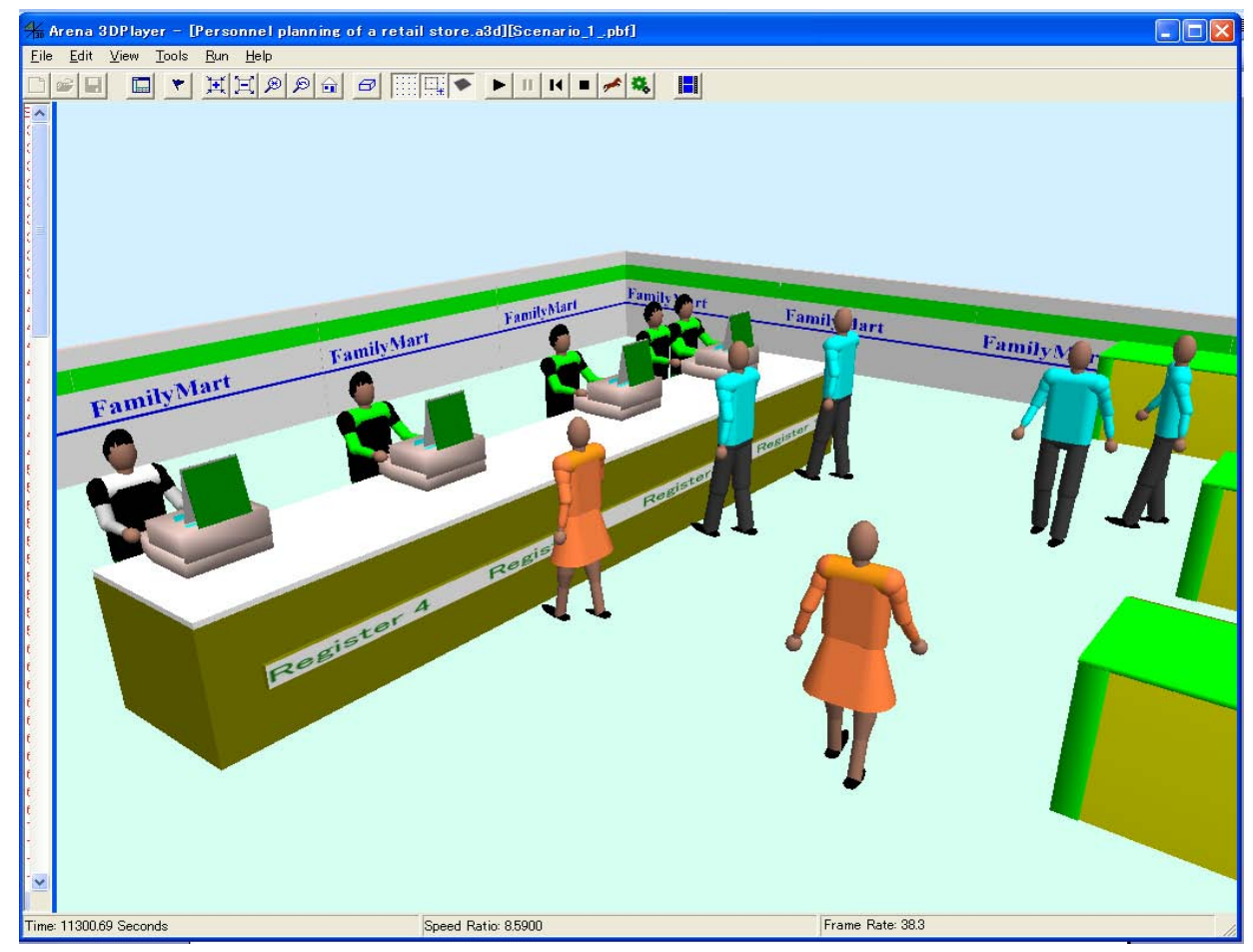

Figure 6: Selected part of the animation. 
Table VI: Selected simulation parameters.

\begin{tabular}{|c|c|c|c|}
\hline \multirow{3}{*}{ Name } & \multicolumn{3}{|c|}{ Parameter } \\
\hline & \multirow{2}{*}{ (a) by one clerk } & \multicolumn{2}{|c|}{ (b) by two clerks } \\
\hline & & 1st clerk & 2nd clerk \\
\hline Removing Time & \multirow{2}{*}{ TRIA(4,6.61*n,6.61*n+3.04) } & TRIA(2,3.17*n,3.17*n+2.48) & - \\
\hline Scanning Time & & - & $\operatorname{TRIA}(2,3.65 * n, 3.65 * n+2.61)$ \\
\hline Picking Time & $\operatorname{TRIA}(1,2,3)$ & $\operatorname{TRIA}(1,2,3)$ & - \\
\hline Packing Time & TRIA(2.40,4.29*n,4.29*n+2.15) & $\operatorname{TRIA}(2.40,4.29 * \mathrm{n}, 4.29 * \mathrm{n}+2.15)$ & - \\
\hline Paying Time & TRIA(8,12,20) & - & TRIA(8,12,20) \\
\hline Returning Time & TRIA(1.5,2,2.5) & TRIA(1.5,2,2.5) & - \\
\hline
\end{tabular}

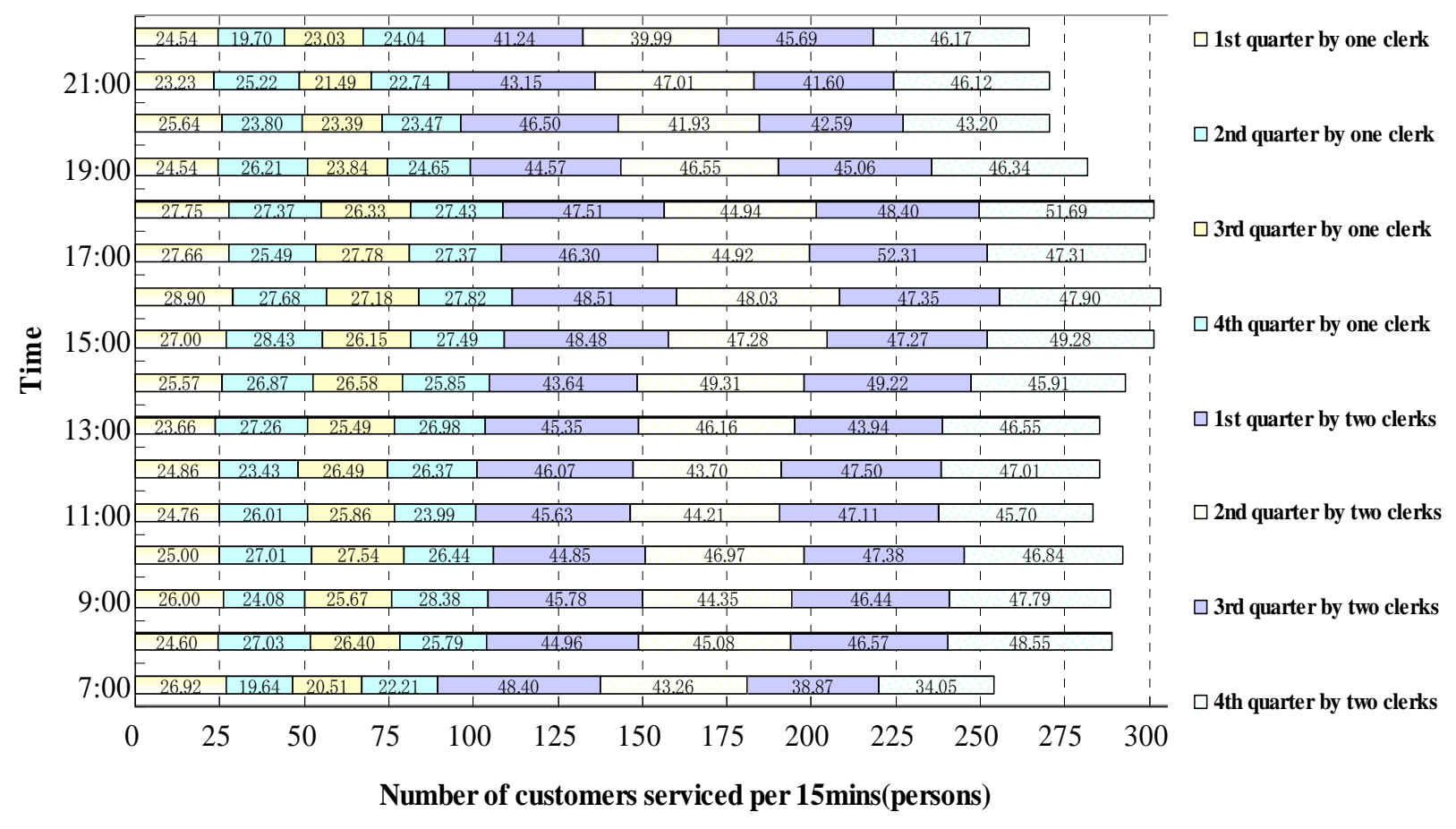

Figure 7: Number of customers served by two patterns of clerk allocation.

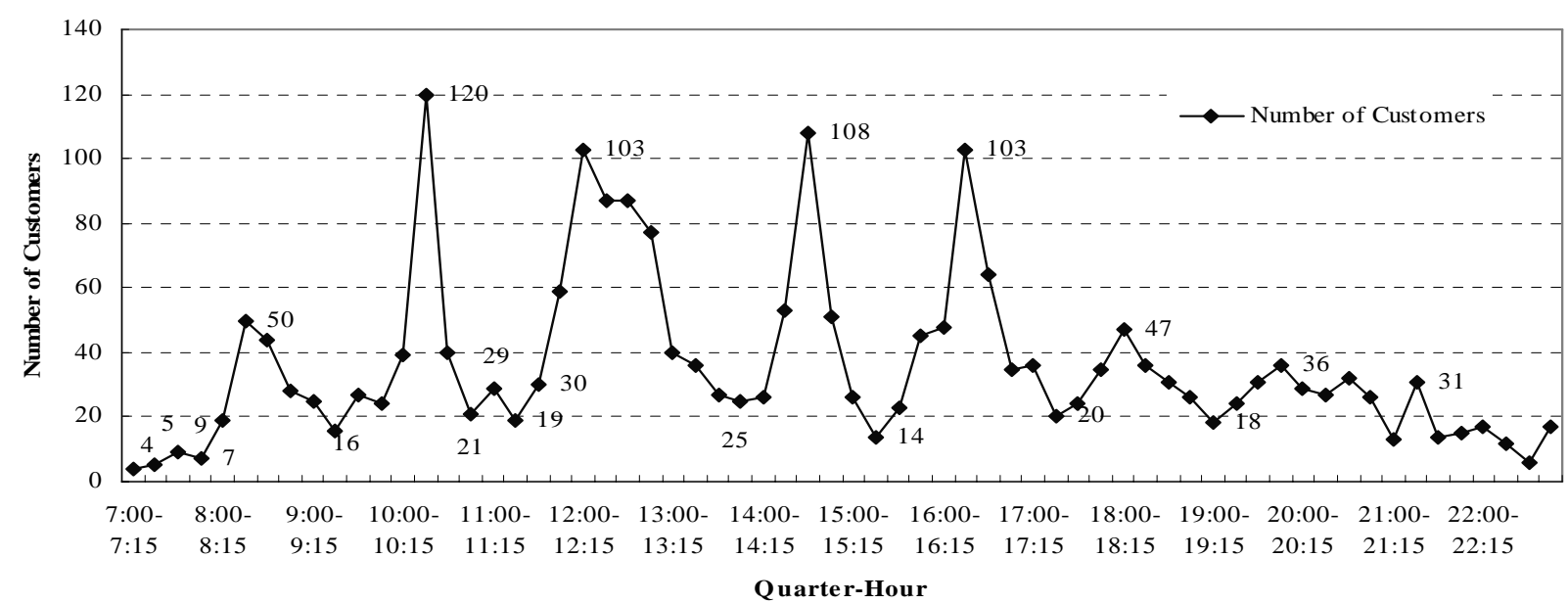

Figure 8: Number of customers appearing per 15 minutes. 
An optimisation IP model was used to seek the optimal allocation pattern during each 15 minutes interval at Step 5. In this case, $i$ symbolises an allocation pattern, and $j$ represents interval index. For this model, the cost of each allocation pattern is given in Table VII.

Define the decision variable

$$
x_{i, j}=1 \text { if allocation pattern } i \text { is used, }=0 \text { if not used; for } j=1,2, \ldots, 64 \text {. }
$$

$\operatorname{Min} Z=187.5 x_{11}+375 x_{21}+562.5 x_{31}+750 x_{41}+937.5 x_{51}+1125 x_{61}+187.5 x_{12}+\cdots+1125 x_{664}$

Subject to:

$$
\begin{array}{rc}
x_{11}+x_{21}+x_{31}+x_{41}+x_{51}+x_{61}=1 & \text { (Interval 1: 7:00-7:15) } \\
x_{12}+x_{22}+x_{32}+x_{42}+x_{52}+x_{62}=1 & \text { (Interval 2: 7:15-7:30) } \\
\cdots & \\
x_{164}+x_{264}+x_{364}+x_{464}+x_{564}+x_{664}=1 & \text { (Interval 64: 22:45-23:00) } \\
26.92 x_{11}+53.85 x_{21}+80.77 x_{31}+107.69 x_{41}+129.17 x_{51}+150.65 x_{61} \geq 4 \\
19.64 x_{12}+39.28 x_{22}+58.91 x_{32}+78.55 x_{42}+102.17 x_{52}+125.79 x_{62} \geq 5
\end{array}
$$

(Interval 2: 7:15-7:30)

$$
24.04 x_{164}+48.09 x_{264}+72.13 x_{364}+96.18 x_{464}+118.31 x_{564}+140.43 x_{664} \geq 17
$$$$
x_{i, j}=0, \text { or } 1, \quad i=1,2, \ldots, 6 ; j=1,2, \ldots, 64
$$

In this case, the first 64 constraints correspond to making selections from the allocation patterns in every interval, as in Eq. (1). Furthermore, the latter 64 constraints correspond to satisfying the expected number of customers appearing at each time interval, as in Eq. (2). At the interval 1 (7:00AM-7:15AM), for instance, $26.92\left(k_{1,1}=26.92\right)$ persons can be served by the allocation pattern $1,53.85\left(k_{2,1}=26.92 \times 2\right)$ persons can be served by the allocation pattern 2, and so on. The right hand side, 4 was the number of customers appearing at the interval 1. Also as may be seen in Fig. 8, 120 persons of customers appears at interval 14 (10:15AM-10:30AM), then $S_{14}=120$. At interval 14, the allocation pattern 1 can serve 26.21 $\left(k_{1,14}=26.21\right)$ persons, and the allocation pattern 2 can be serve $52.42\left(k_{2,14}=26.21 \times 2\right)$ persons, and so on.

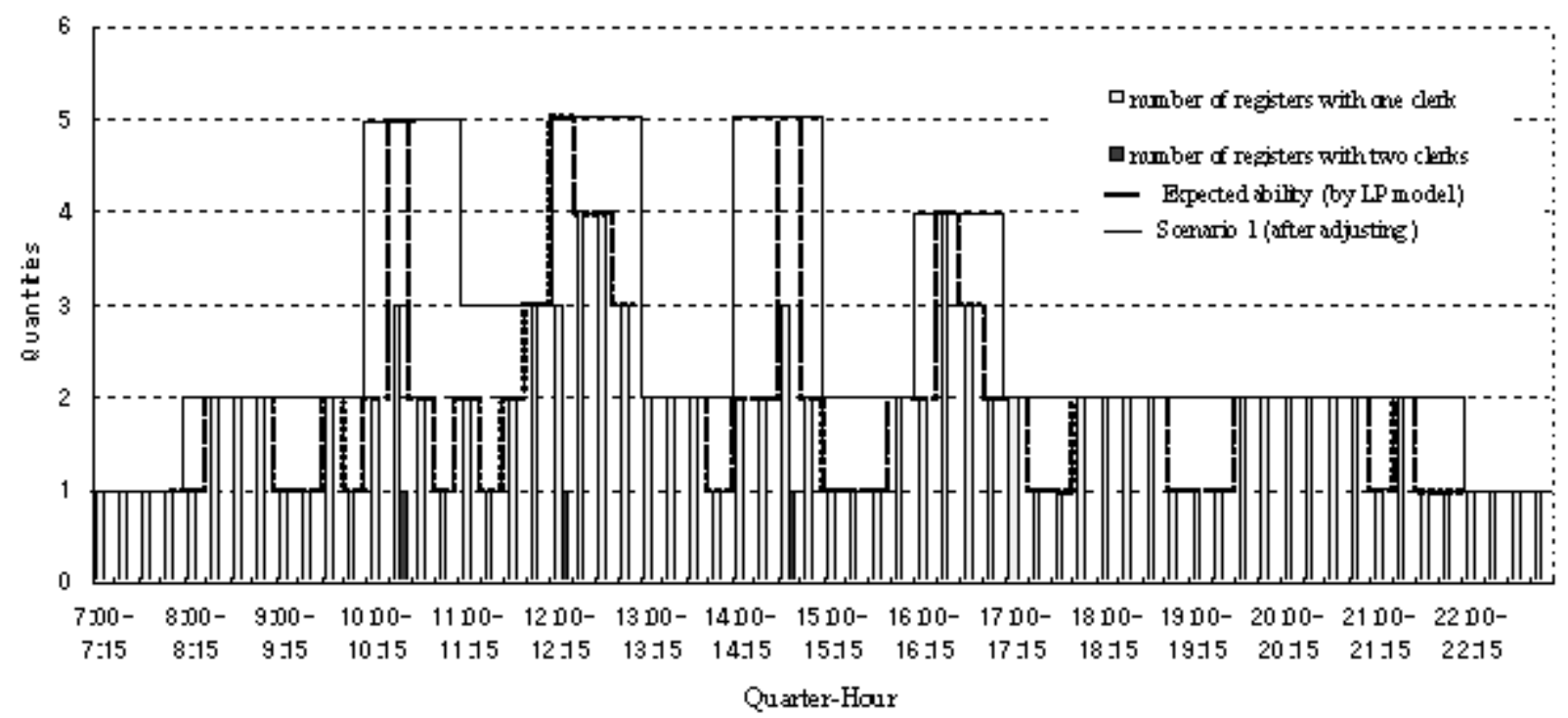

Figure 9: Result by performing IP model. 
For Step 6, the result of the IP model was obtained as shown in Fig. 9. During the peak times (approximately 10:15AM-10:30AM; 12:00PM-1:00PM; 2:30PM-2:45PM) of 1 July, 2008, it was recommended that the store service with pattern 5 indicated in Table VII. A robust result was obtained, by adjusting expected abilities of salesclerks from per 15-minutes to hours (Scenario 1). Then, Scenario 1 is inputted into the simulation model for Step 7 to analyse customer waiting time. Fig. 10 shows the average service level of Scenario 1 . The service level target 95/60 seconds was not satisfied because service levels for the peak times were much lower, for instance: (1) 12PM-1PM 39/60, (2) 10AM-11AM 50/60, and (3) 2PM3PM 68/60.

At Step 8, as the service level from 12PM to $1 \mathrm{PM}$ is minimum than any other time, Scenario 2 was designed where another clerk should be added during this peak time. By repeating the simulation model, the average service level was improved to 94/60 seconds, as shown in Fig. 11. In spite of this, the service level target was not achieved. In a similar way, the peak time from 10AM to 11AM was selected to add another clerk in Scenario 3, as shown in Fig. 12, since the service level of this peak time (50/60) was minimum in Scenario 2. After performing the simulation model, the service level was enhanced from 94/60 seconds to 97/60 seconds. Fig. 13 shows the number of clerks for each scenario, while Table VII shows the total personnel expenses and service level for each scenario compared with the current personnel allocation status.

Table VII: Summary for each scenario.

\begin{tabular}{|c|c|c|c|c|c|c|c|c|}
\hline & \multicolumn{2}{|c|}{ AS-IS } & \multicolumn{2}{|c|}{ Scenario 1} & \multicolumn{2}{|c|}{ Scenario 2} & \multicolumn{2}{|c|}{ Scenario 3} \\
\hline Total Expenses (Thousand Yen & \multicolumn{2}{|c|}{42} & \multicolumn{2}{|c|}{31.5} & \multicolumn{2}{|c|}{32.25} & \multicolumn{2}{|c|}{33} \\
\hline Average Service Level & \multicolumn{2}{|c|}{$87 / 60$} & \multicolumn{2}{|c|}{$90 / 60$} & \multicolumn{2}{|c|}{$94 / 60$} & \multicolumn{2}{|c|}{$97 / 60$} \\
\hline Peak Interval & $\begin{array}{c}\text { Allocation } \\
\text { Pattern }\end{array}$ & $\begin{array}{l}\text { Service } \\
\text { Level }\end{array}$ & $\begin{array}{l}\text { Allocation } \\
\text { Pattern }\end{array}$ & $\begin{array}{l}\text { Service } \\
\text { Level }\end{array}$ & $\begin{array}{l}\text { Allocation } \\
\text { Pattern }\end{array}$ & $\begin{array}{l}\text { Service } \\
\text { Level }\end{array}$ & $\begin{array}{l}\text { Allocation } \\
\text { Pattern }\end{array}$ & $\begin{array}{l}\text { Service } \\
\text { Level }\end{array}$ \\
\hline $10: 00-11: 00$ & 4 & $43 / 60$ & 5 & $50 / 60$ & 5 & $50 / 60$ & 6 & $100 / 60$ \\
\hline $12: 00-13: 00$ & 5 & $38 / 60$ & 5 & $39 / 60$ & 6 & $99 / 60$ & 6 & $100 / 60$ \\
\hline $14: 00-15: 00$ & 4 & $61 / 60$ & 5 & $68 / 60$ & 5 & $72 / 60$ & 5 & $71 / 60$ \\
\hline
\end{tabular}

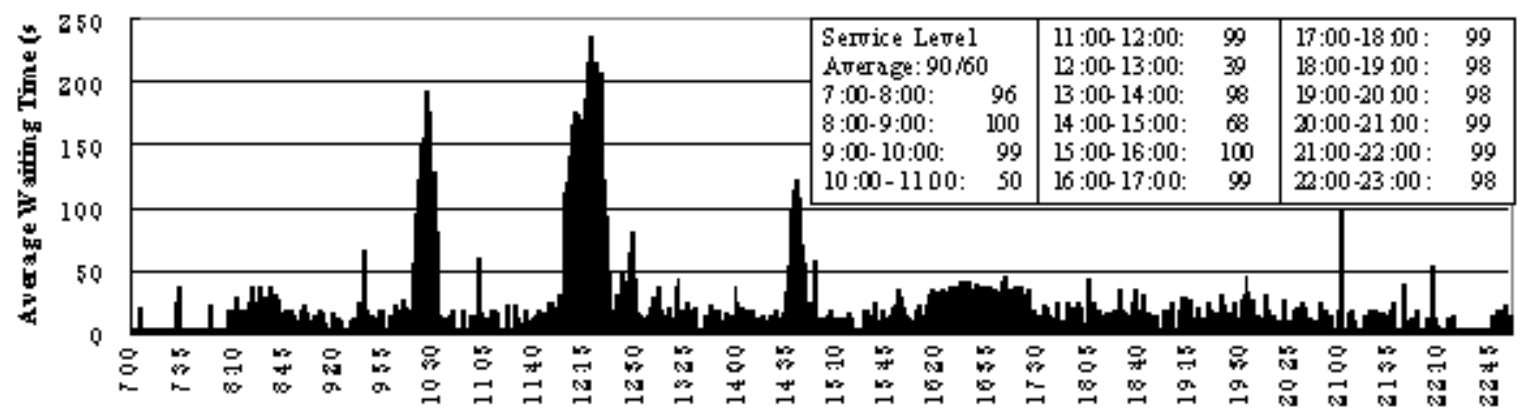

Figure 10: Service level (Scenario 1).

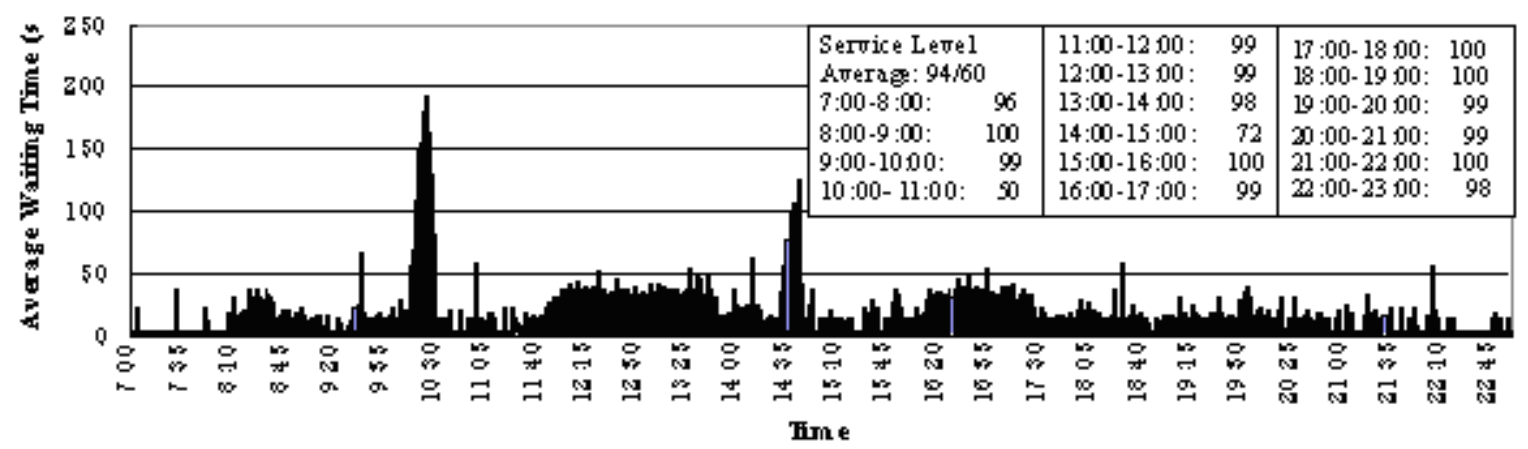

Figure 11: Service level (Scenario 2). 


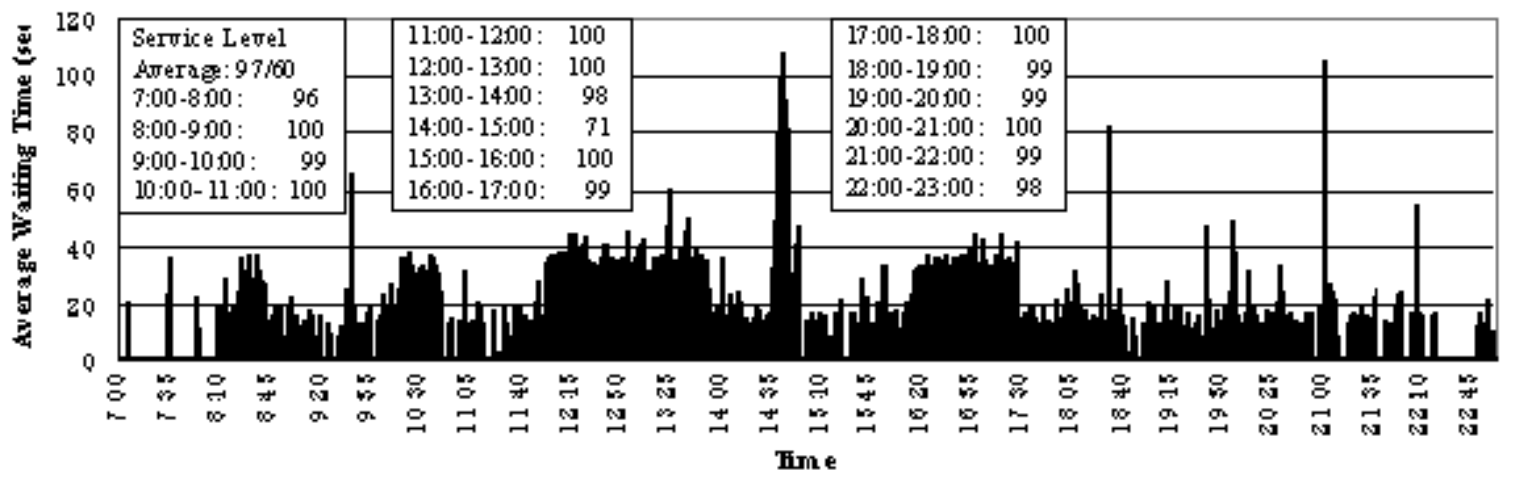

Figure 12: Service level (Scenario 3).

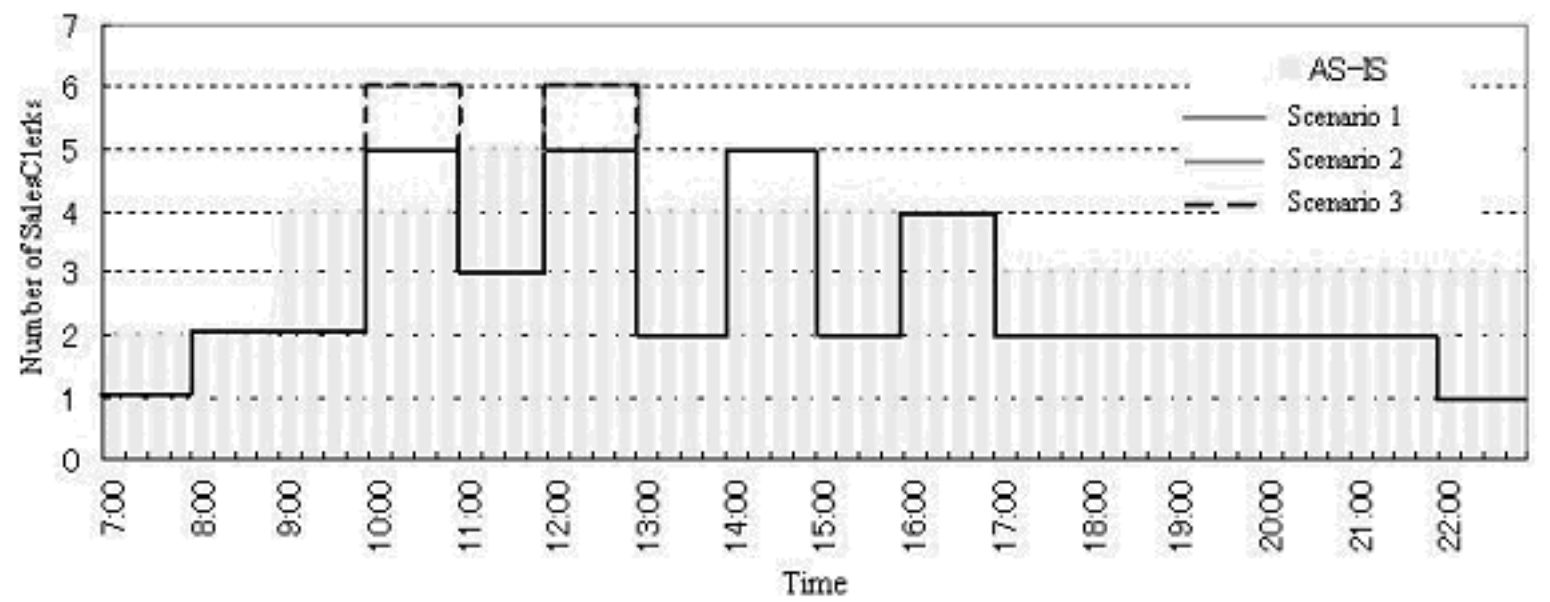

Figure 13: Number of clerks for each scenario.

\section{CONCLUSIONS}

In general, a regular decision-making basis of the personnel planning comprises the customer number, the frequency of customers coming into stores, and average service time of customers. In this paper, by making use of the actual Point of Sales (POS) data, a procedure was proposed to aid retail stores management in determining the optimal allocation pattern necessary to achieve a specific goal, which is the service level target during each interval. In addition, the proposed procedure was applied to a real case in order to confirm its effectiveness. The procedure is generic and can easily be expanded to model other situations such as an off-season of the store and other retail stores. Finally, this study disregarded the impact of incremental arrival of the total number of customers. The author believes that it would be interesting to analyse this issue on personnel planning in conjunction with a sensitivity analysis.

\section{ACKNOWLEDGEMENTS}

The author wishes to express sincere gratitude to FamilyMart Company, Ltd. for their cooperation in completing this research. Special thanks should be expressed to Mr. Ueda, Mr. Takahashi, and Mr. Fujita of FamilyMart Corporation in acknowledgment of this research. This research was supported by Grant-in-Aid for Asian CORE Program of Japan Society for the Promotion of Science (JSPS). 


\section{REFERENCES}

[1] Centeno, M. A.; Giachetti, R.; Linn, R.; Ismail, A. M. (2003). A simulation-ILP based tool for scheduling ER staff, Proceedings of the 2003 Winter Simulation Conference, 1930-1938

[2] Takakuwa, S.; Okada, T. (2005). Simulation analysis of inbound call center of a city-gas company, Proceedings of the 2005 Winter Simulation Conference, 2026-2033

[3] Takakuwa, S.; Wijewickrama, A. (2008). Optimizing staffing schedule in light of patient satisfaction for the whole outpatient hospital ward, Proceedings of the 2008 Winter Simulation Conference, 1500-1508

[4] Wijewickrama, A.; Takakuwa, S. (2004). Simulation analysis of patient flows and staffing schedules in an outpatient department, Sri Lankan Journal of Management, Vol. 9, No. 3\&4, 111127

[5] Baydar, C. (2003). Agent-based modeling and simulation of store performance for personalized pricing, Proceedings of the 2003 Winter Simulation Conference, 1759-1764

[6] Smith, D. J. (1994). Computer simulation applications in service operations: a case study from the leisure industry, The Service Industries Journal, Vol. 14, No. 3, 395-408

[7] Fu, F.; Piplani, R. (2000). Multi-Agent Enabled Modeling And Simulation Towards Collaborative Inventory Management In Supply Chains, Proceedings of the 2000 Winter Simulation Conference, 1763-1771

[8] King, R. E.; Moon, K. (1999). Quick Response Replenishment: A Case Study, Proceedings of the 1999 Winter Simulation Conference, 1341-1349

[9] Joines, J. A.; Gupta, D.; Gokce, M. A.; King, R. E.; Kay, M. G. (2002). Supply Chain MultiObjective Simulation Optimization, Proceedings of the 2002 Winter Simulation Conference, 1306-1314

[10] Adams, J.; Flatto, J.; Gardner, L. (2005). Combining Hands-On, Spreadsheet and Discrete Event Simulation to Teach Supply Chain Management, Proceedings of the 2005 Winter Simulation Conference, 2329-2337

[11] Miwa, K.; Takakuwa, S. (2008). Simulation modeling and analysis for in-store merchandizing of retail stores with enhanced information technology, Proceedings of the 2008 Winter Simulation Conference, 1702-1710

[12] Ignizio, J. P. (1982). Linear programming in single- and multiple-objective systems, Prentice-Hall, Englewood Cliffs, New Jersey

[13] Ignizio, J. P.; Cavalier, T. M. (1994). Linear programming, Prentice-Hall, Englewood Cliffs, New Jersey

[14] Kelton, W. D.; Sadowski, R. P.; Sturrock, D. T. (2007). Simulation with ARENA $4^{\text {th }}$ ed., McGraw-Hill, New York 